2016 - Volume: 17 Number: 3

Page: 594 - 604

DOI : $10.18038 / \mathrm{btda} .45571$

Received: 04 August 2016

Revised: 21 September 2016

Accepted: 27 September 2016

\title{
THE EFFECT OF COLLECTOR, FROTHER DOSAGE AND THEIR INTERACTION ON THE FLOTATION OF BOTTOM ASH BY FULL FACTORIAL DESIGN
}

\author{
Derya ÖZ AKSOY* \\ Department of Mining Engineering, Faculty of Engineering and Arcitechture, \\ Eskişehir Osmangazi University, Eskişehir, Turkey
}

\begin{abstract}
Bottom ash samples taken from Mihallicik-Cayirhan coal-fired power plant operated by Park Termik Company were used in this study. Combustible matter percentage in the samples is around $9 \%$. The aims of this study are to recover combustible matter in the bottom ash by flotation and to evaluate the usability of floatation tailings in the construction industry by reducing the percentage of combustible matter less than $6 \%$ as to be accordance with ASTM C 618. Flotation experiments were designed with full factorial design to investigate the effect of collector and frother dosage on the recovery of combustible matter. In this study, statistical experimental design methods were utilized in the flotation experiments, and therefore, the effects of collector and frother dosages on the ash and unburned carbon contents were not only modeled, but the interaction between these factors were also determined in the unburned carbon floatation. Two models obtained at this study were found to be significant statistically. The results have shown that there is an interaction between collector and frother dosages in the floatation selectivity (in the ash content), whereas this interaction was found to be insignificant statistically at the selected parameter levels for this sample in the case of unburned carbon recovery.
\end{abstract}

Keywords: Flotation, Bottom ash, Unburned carbon recovery, Experimental design

\section{INTRODUCTION}

In the developed countries, increasing energy efficiency and the electricity consumption per capita are among the basic factors forming energy policies [1]. The increase in the world's average of electricity consumption is proposed as $60 \%$ while the increase in China's and India's consumption is expected to be $200 \%$ by the year 2030 with respect to year 2004 [2].

The increase expectation in electricity energy consumption in the future makes the sources used in the energy production a current issue. The major sources of electricity production can be listed as fossil fuels, renewable energy sources and nuclear energy. In particular, coal will continue to be the world's energy cornerstone, providing more incremental energy over that same time period than any other single fuel [3]. Besides, in Turkey, the share of local coal sources is very low in energy production. The reason for this situation is given as follows; our lignite has low calorific value and high ash-sulfur content which can result in serious environmental problems if they are used without any treatment. However, these problems can be reduced to acceptable levels with the help of applicable methods before, during and after combustion. Another serious problem for the coal-fired power plants is the solid waste problems. Waste created by a typical plant includes thousands tons of fly ash, bottom ash and sludge, annually. These wastes which are generally stored in waste ponds can cause for acidic mine drainage in addition to economic losses due to unburned carbon content. This is an unavoidable result of the usage of coal in the electric power production.

The cumulative amount of solid waste by coal-fired power plants in USA, EU and Turkey is around 125,100 and 24 million tons, respectively, and these values continue to increase [4]. The waste recovery and usage for rehabilitation purposes are getting important for the assessment of this waste in an environment-friendly and sustainable way. The rate of waste recovery and usage in coal-fired power

*Corresponding Author: deryaoz@gmail.com 
plants in EU and USA is $90 \%$ and $40 \%$, respectively [5]. These wastes are generally used in construction, ceramic and glass industries [6].

In a study, it is stated that fly ash was used instead of Portland cement and bottom ash was used instead of aggregate during highway construction [7]. As it can be seen from the industrial applications fly ash can be used without any further processing. On the other hand, combustible matter content in the bottom ash is an important factor for the usage of bottom ash in civil construction industry [8]. Some studies showed that higher combustible content in the ash decreases the pozzolan activity [6, 8-11]. It is also reported that carbon in the ash interacts with the chemical additives that forms micro air bubbles during concrete manufacturing, resulting the increase in the consumption of these chemicals. The ASTM C618 specification limits loss-on-ignition (LOI) to $6 \%$ for the usage of ash as raw material although the allowed carbon content varies according to country regulations around the world $[11,14]$.

Combustible matter content in the bottom ash of coal-fired power plants varies according to combustion efficiency and is generally around $10 \%[6,11-13]$. In our country, this content does not fall below $10 \%$ because of the fact that most of the power plants in Turkey have traditional combustion systems and have low combustion efficiency. Therefore, this high percent of combustible matter makes applying the enrichment process to bottom ash necessary. Reducing combustible matter content of bottom ash increases the potential usage as raw material for different industries. Besides, recovered unburned combustible matter can be used as fuel in the coal-fired power plants [6].

The studies related bottom ash in the literature are focusing on the recycle of unburned combustible matter. Floatation method which is a physico-chemical process is generally used to recover the unburned combustible matter in the bottom ash [7, 10, 12-14].

Along the studies about the enrichment of bottom ash, there are also studies in literature related with the usage of bottom ash as raw material in cement, concrete, and ceramic industries [9, 15]. In a report of American federal highway agency (FHA), it is stated that the life span of bridge and highways constructed with coal ashes is higher than the life span of bridge and highways constructed with only Portland cement [4].

All these studies have shown the problems caused by higher combustible matter content in the bottom ash and advantages of separation of these matters from the inorganic structure.

In this study, to investigate the effects of some flotation parameters on combustible matter recovery, a statistical method is used. Collector dosage, frother dosage and their interactions which are considered to be effective parameters on the ash content and combustible recovery of floatation concentrate were described with mathematical models by using Full Factorial Design (FFD) method in the flotation of bottom ash. Finally, the floatation tailings will be used in another multi-disciplinary study where these tailings will be used in highway construction.

\subsection{Statistical Design of Experiment}

Statistical design of experiments has several advantages over classical optimization methods where one parameter is optimized at each time [16]. In order to obtain the required data in statistical designs, all experiments are carried out in planned way and the results can be analyzed systematically by means of variance analysis. The obtained data also can be assessed for optimization goals [17]. Full factorial design (FFD) is one of the methods used to evaluate the effects of parameters and their interactions [18]. 
The number of experiments in FFD is calculated as follows:

$$
N=3^{k} * n
$$

where $\mathrm{N}$ is the number of experiments, $\mathrm{k}$ is the number of parameters, and $n$ is the number of replicates. In order to increase the reliability of statistical analysis, all experiments are conducted two times.

\section{MATERIAL AND METHODS}

\subsection{Material}

The bottom ash samples used in this study were taken from Cayirhan lignite-fired power plant located in the middle part of Turkey. Samples were dried in air and crushed with jaw crusher to $-10 \mathrm{~mm}$ and again dried in at $60^{\circ} \mathrm{C}$. In the lights of the results of earlier studies, samples were ground to $-0.106 \mathrm{~mm}$ by closed circuit grinding. Combustible matter content of the samples is found to be $9 \%$ by ash analysis. Flotation experiments were performed at this size fraction.

\subsection{Methods}

Experimental studies were carried out by using laboratory type floatation machine with 1.5 litre cell at the Mineral Processing Laboratory of Eskişehir Osmangazi University.

In the experiments, the effects of collector and frother dosages on the carbon content and combustible recovery are investigated while other parameters are kept at constant values which were determined from preliminary studies and data found in the literature [14, 19, 20, 21, 22, 23]. $\mathrm{pH}$ level was chosen as natural $\mathrm{pH}$. The values of constant parameters are given in Table 1. In floatation studies, Methyl Isobutyl Carbinol (MIBC) which is a type of synthetic alcohol and widely used in coal floatation was used as frother. Sodium silicate $\left(\mathrm{Na}_{2} \mathrm{SiO}_{3}\right)$ was used as dispersant.

Table 1. The values of constant parameters

\begin{tabular}{ll|ll} 
Parameter & Level & Parameter & Level \\
\hline Solid Ratio $(\%)$ & 15 & Dispersant amount $(\mathrm{g} / \mathrm{t})$ & 1000 \\
Particle size $(\mathrm{mm})$ & $-0,106$ & Collector Type & Fuel-oil \\
$\mathrm{pH}$ & 8,5 & Conditioning time $(\mathrm{min})$ & 6 \\
Strring speed $(\mathrm{rpm})$ & 1250 & Frother Type & MIBC \\
Pulp temperature $\left({ }^{\circ} \mathrm{C}\right)$ & 21.5 & Airation rate $(1 / \mathrm{min})$ & 5 \\
Dispersent type & $\mathrm{Na}_{2} \mathrm{SiO}_{3}$ & Flotation time $(\mathrm{sec})$ & 60
\end{tabular}

As it is mentioned above, experiments are designed according to FFD. Two parameters and the three levels of parameters whose effects are to be investigated are determined and given in Table 2. The number of experiments was determined as 18 for two factors which have three levels according to Equation 2.

Table 2. Parameters and their levels

\begin{tabular}{lccc}
\multicolumn{1}{c}{ Parameter } & low & $\begin{array}{c}\text { Levels } \\
\text { middle }\end{array}$ & high \\
\hline Collector dosage $(\mathrm{g} / \mathrm{t})$ & 500 & 1500 & 2500 \\
Frother dosage $(\mathrm{g} / \mathrm{t})$ & 100 & 200 & 300
\end{tabular}

Generally, both in laboratory and large scale flotation processes, for the purpose of homogeneous dispersion of collectors in pulp, emulsifier reagents are used to form small oil drops [24, 25]. Toluene is generally used for reducing the viscosity of petroleum products. Therefore, in this study, toluene is 
Öz Aksoy / Anadolu Univ. J. of Sci. and Technology - A - Appl. Sci. and Eng. 17 (3) - 2016

used as an emulsifier agents fuel oil is used as flotation collector and mixed with toluene at the ratio of $1 / 2$ by volume (fuel oil-toluene).

After each flotation experiments, ash content of floatation products was analyzed according to ASTM D3174-12 [26] and combustible recovery (CR) was calculated by Equation 2 given below:

$$
C R(\%)=\frac{\% \text { wt of concentrate } x(100-\text { Ash content of concentrate })}{100-\text { Ash content of feed })}
$$

Trial version of Design Expert 7.0.0 software was used for statistical design. In the statistical analysis, confidence level is chosen as $95 \%$.

\section{RESULTS AND DISCUSSION}

According to the determined design, 18 experiments for 9 different conditions were randomly carried out. Carbon Content (CC) and combustible recoveries of concentrate obtained from these experiments are given along with design matrix (Table 3 ).

Table 3. Carbon content and combustible recoveries of flotation concentrate with design matrix

\begin{tabular}{|c|c|c|c|c|c|c|}
\hline \multirow{2}{*}{$\begin{array}{l}\text { Test } \\
\text { No }\end{array}$} & \multirow{2}{*}{$\mathbf{A}^{*}$} & \multirow{2}{*}{$\mathbf{B}^{* * *}$} & \multicolumn{2}{|c|}{ Carbon Content (\%) } & \multicolumn{2}{|c|}{$\begin{array}{c}\text { Combustible Recovery } \\
(\%)\end{array}$} \\
\hline & & & $1^{\text {st }}$ run & $2^{\text {nd }}$ run & $1^{\text {st }}$ run & $2^{\text {nd }}$ run \\
\hline 1 & 500 & 100 & 14.14 & 16.09 & 16.09 & 12.50 \\
\hline 2 & 1500 & 100 & 25.35 & 32.86 & 29.86 & 22.38 \\
\hline 3 & 2500 & 100 & 28.10 & 35.48 & 32.48 & 24.74 \\
\hline 4 & 500 & 200 & 38.06 & 38.31 & 21.98 & 23.17 \\
\hline 5 & 1500 & 200 & 31.26 & 34.38 & 34.53 & 37.25 \\
\hline 6 & 2500 & 200 & 35.45 & 34.24 & 46.69 & 47.48 \\
\hline 7 & 500 & 300 & 34.70 & 35.42 & 34.82 & 30.83 \\
\hline 8 & 1500 & 300 & 39.40 & 31.34 & 43.94 & 50.24 \\
\hline 9 & 2500 & 300 & 32.33 & 36.82 & 51.61 & 56.41 \\
\hline
\end{tabular}

The results of the experiments were subjected to variance analysis for both response variables, and regression models were formed. Besides, the graphics showing the main effect of parameters and parameters interactions were prepared by keeping other parameter at its middle level.

\subsection{Effects of Parameters on Carbon Content of the Flotation Concentrate}

The obtained carbon content (CC) values are subjected to analysis of variance (ANOVA). When the results of quadratic model which includes all possible terms are examined, both linear and parabolic effect of collector dosage on carbon content of concentrate is found to be statistically meaningless. However, the interaction between collector and frother dosages is found to be statistically significant. For this reason, the meaningless terms are omitted, but linear term of collector dosage is kept in order to keep model hierarchy. The reduced results of variance analysis (ANOVA), regression coefficient values and predicted regression coefficient values are given in Table 4.

As a result of this variance analysis, the regression model given in Equation 3 was obtained in terms of actual values.

$$
C C(\%)=-10.9208+0.0107 A+0.3172 B-4.29 \times 10^{-5} A B-5.11 \times 10^{-4} B^{2}
$$


Öz Aksoy / Anadolu Univ. J. of Sci. and Technology - A - Appl. Sci. and Eng. 17 (3) - 2016

Table 4. The reduced results of variance analysis for carbon content

\begin{tabular}{ll} 
Term & Value \\
\hline Model P Value & 0.0023 \\
Error $\mathrm{p}$ Value & 0.0702 \\
$\mathrm{R}^{2}$ & 0.6979 \\
$\mathrm{R}^{2}{ }_{\text {adj }}$ & 0.6049 \\
$\mathrm{R}^{2}$ Pred & 0.4286 \\
Mean & 31.87 \\
Standart Dev. & 4.42 \\
\hline Significant Terms $(\mathrm{p}<0.05)$ & $\mathrm{B}, \mathrm{AB}, \mathrm{B}^{2}$
\end{tabular}

When Table 4 is examined, this model is found to be statistically significant because its p-value (0.0023) is less than 0.05 and $p$-value of experimental error term (0.0702) is greater than 0.05 .

Predicted and actual carbon content are given in Figure. 1, graphically. As it can be seen from Figure 1 and Table 4, predicted carbon content based on Equation 2 represents approximately $70 \%$ of actual carbon content. Moreover, the predicted regression coefficient is greater than 0.2 with approximately 0.43 and this is another indicator of model strength.

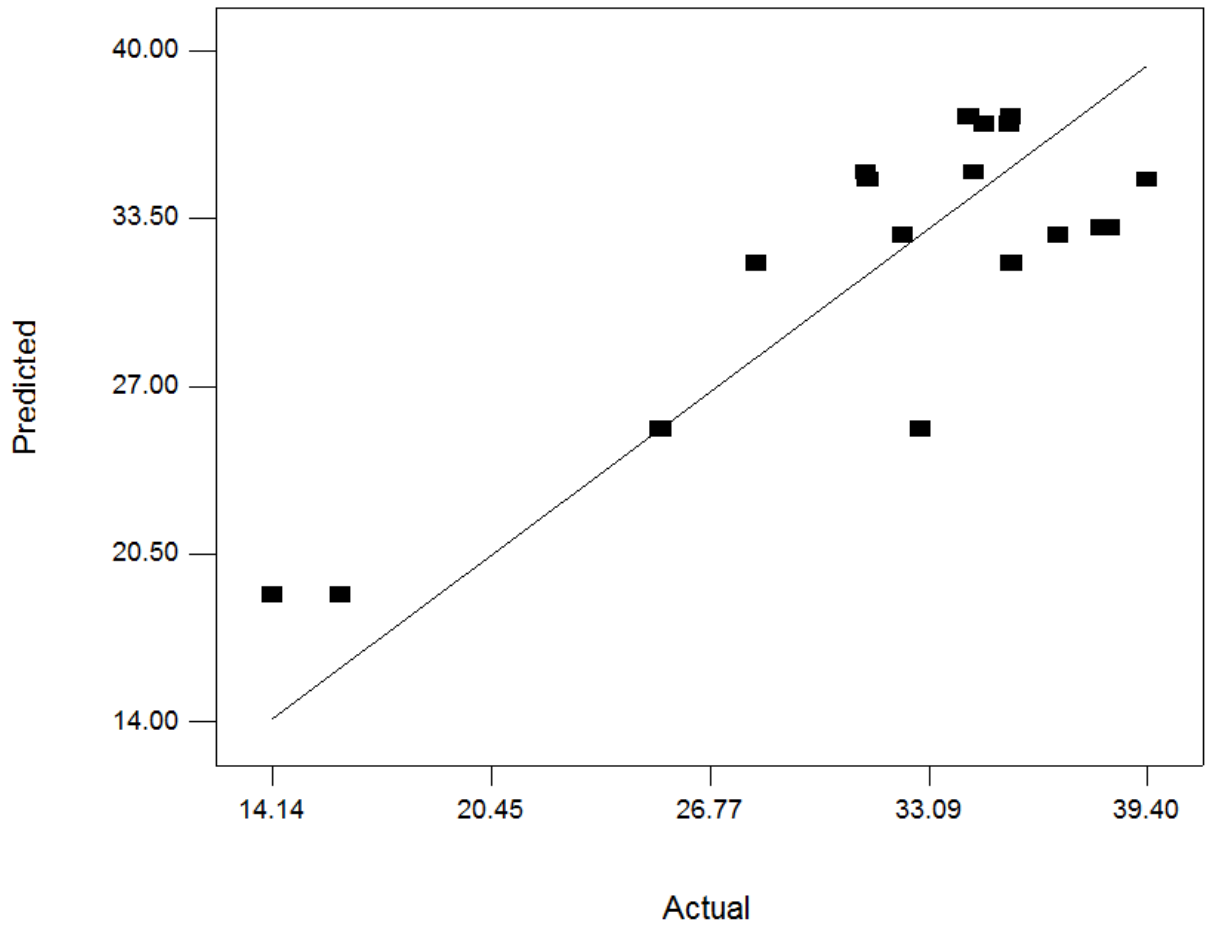

Figure 1. Predicted and actual ash content $\left(\mathrm{R}^{2}=0.6979\right)$

Main effects of parameters are shown in Figure 2. As it can be seen from Figure 2, linear and quadratic effects of collector dosage are insignificant. But, linear and quadratic effects of frother dosage are significant. 
Öz Aksoy / Anadolu Univ. J. of Sci. and Technology - A - Appl. Sci. and Eng. 17 (3) - 2016

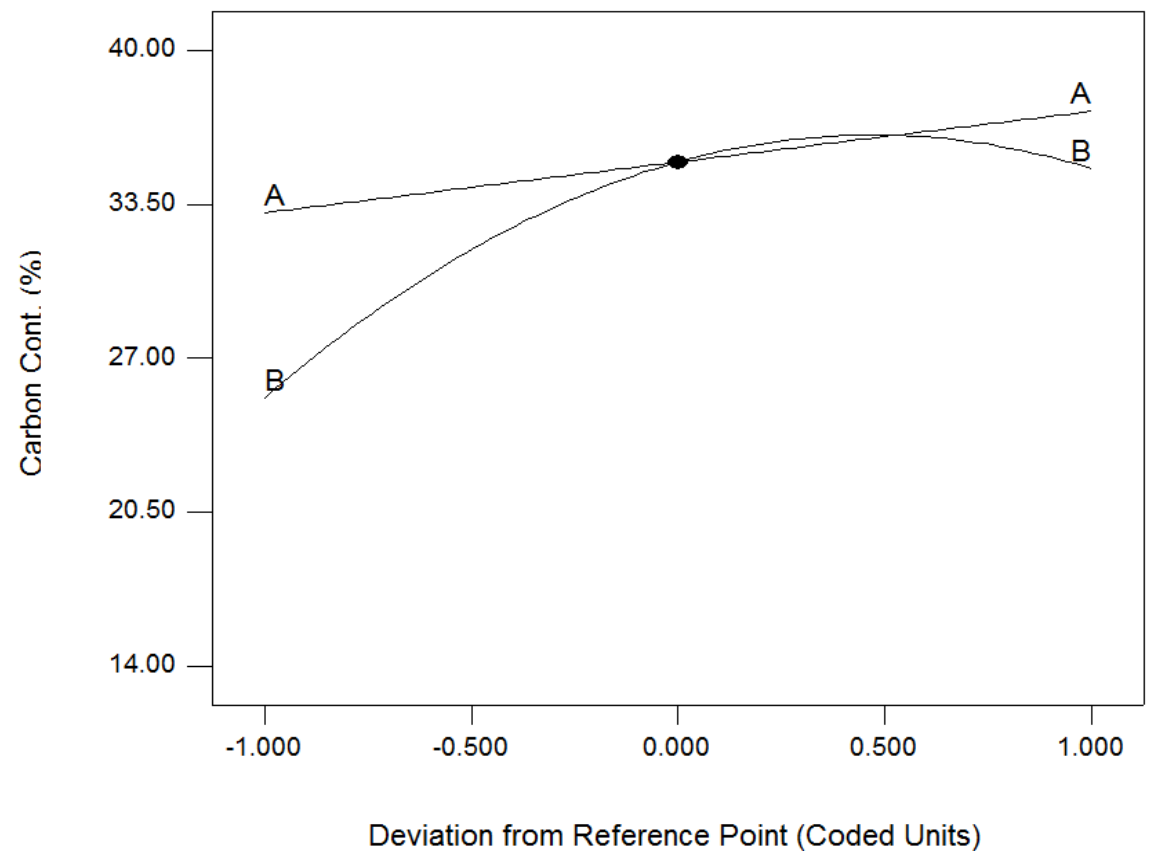

Figure 2. Main effect graphics of parameters for carbon content

The interaction graphic is given in Figure 3. As it can be seen from the Figure 3, an increase in the collector dosage increases the carbon content of concentrate at low frother dosage $(100 \mathrm{~g} / \mathrm{t})$. When the frother dosage is at a high level $(300 \mathrm{~g} / \mathrm{t})$, the increase in the collector dosage decreases the carbon content of the concentrate.

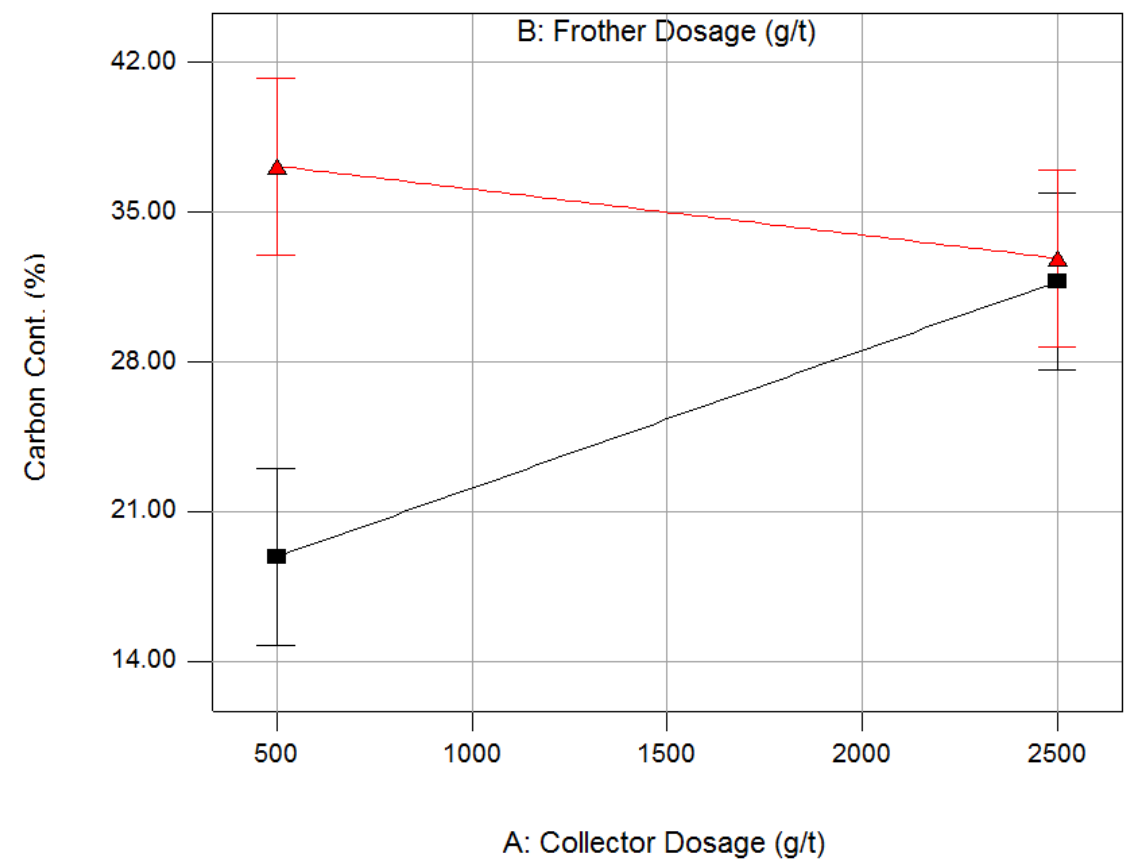

Figure 3. Interaction effects of parameters on carbon content 


\subsection{Effects of Parameters on Combustible Recovery of The Clean Coal}

The obtained combustible recoveries are also subjected to analysis of variance (ANOVA). When the results of quadratic model which includes all possible terms are examined, the linear effects of both parameters are found to be significant but quadratic effects are found to be insignificant. The interaction between collector and frother dosages is found to be statistically insignificant. However, the insignificant terms are omitted, but interaction term is kept because of the fact that one of the main objective of this study is to investigate the effect of interaction. The reduced results of variance analysis (ANOVA), regression coefficient values and predicted regression coefficient values are given in Table 5 .

Table 5. The reduced results of variance analysis for combustible recovery

\begin{tabular}{ll} 
Term & Value \\
\hline Model P Value & $<0.0001$ \\
Error $\mathrm{p}$ Value & 0.3004 \\
$\mathrm{R}^{2}$ & 0.931 \\
$\mathrm{R}^{2}$ adj & 0.9162 \\
$\mathrm{R}^{2}$ Pred & 0.8746 \\
Mean & 34.28 \\
Standart Dev. & 3.73 \\
\hline Significant Terms $(\mathrm{p}<0.05)$ & $\mathrm{A}, \mathrm{B}$
\end{tabular}

As a result of this variance analysis, the regression model given in Equation 4 was obtained.

$$
C R(\%)=2.7944+0.0066 A+0.0824 B+0.00001 A B
$$

When Table 5 is examined, this model is found to be statistically significant because its p-value $(<0.0001)$ is less than 0.05 and p-value of experimental error term $(0.3004)$ is greater than 0.05 . Predicted and actual combustible recovery are given in Figure 4 graphically. As it can be seen from this figure and Table 5, predicted combustible recovery values (regression coefficient) represents approximately $93 \%$ of actual combustible recovery values. Moreover, the predicted regression coefficient is very close as 0.8746 with regression coefficient. This indicates that the model is very strong.

Main effects of parameters are shown in Figure 5. As it can be seen from Figure 5, the increase in both parameter's dosage causes combustible recovery to increase linearly.

In Figure 6, the interaction between collector and frother dosage is given. When this graphic is examined, it can be said that the increase in the collector dosage at different frother dosages causes the same effect on the combustible recovery, which can be interpreted as there is no interaction between these two parameters. 
Öz Aksoy / Anadolu Univ. J. of Sci. and Technology - A - Appl. Sci. and Eng. 17 (3) - 2016

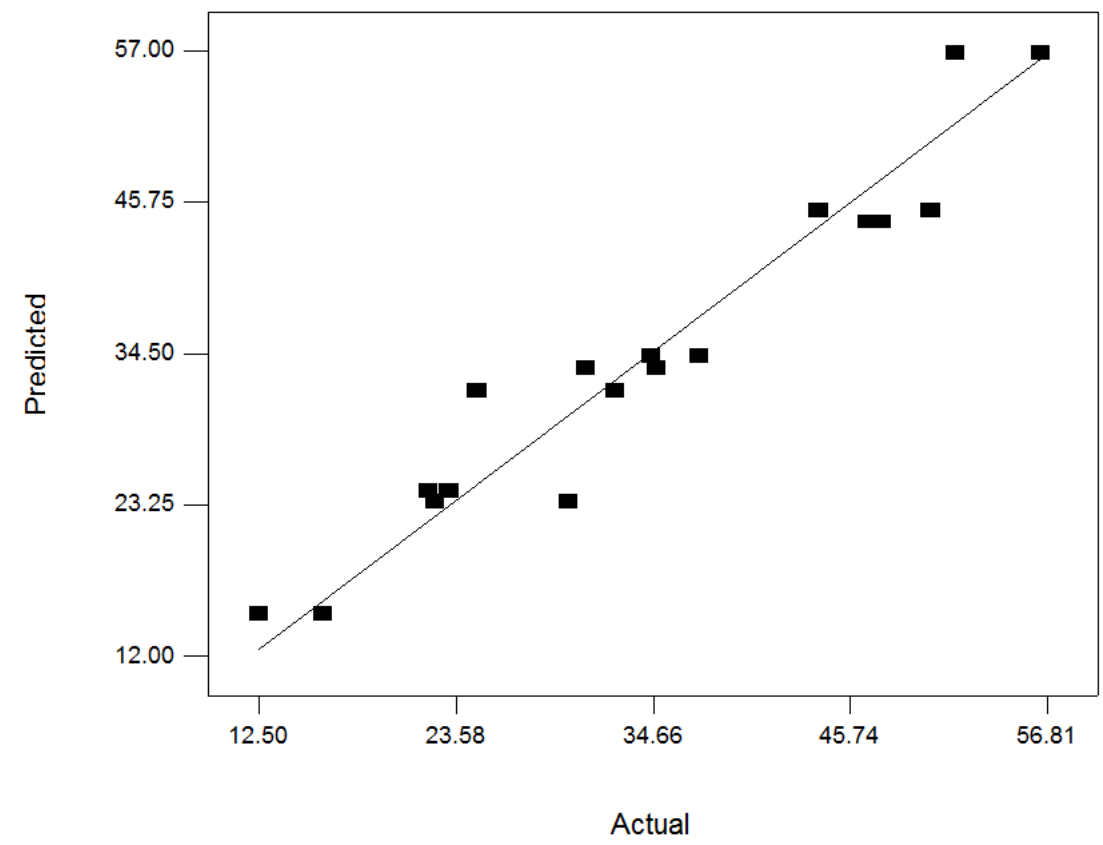

Figure 4. Predicted and actual combustible recovery values $\left(\mathrm{R}^{2}=0.9310\right)$

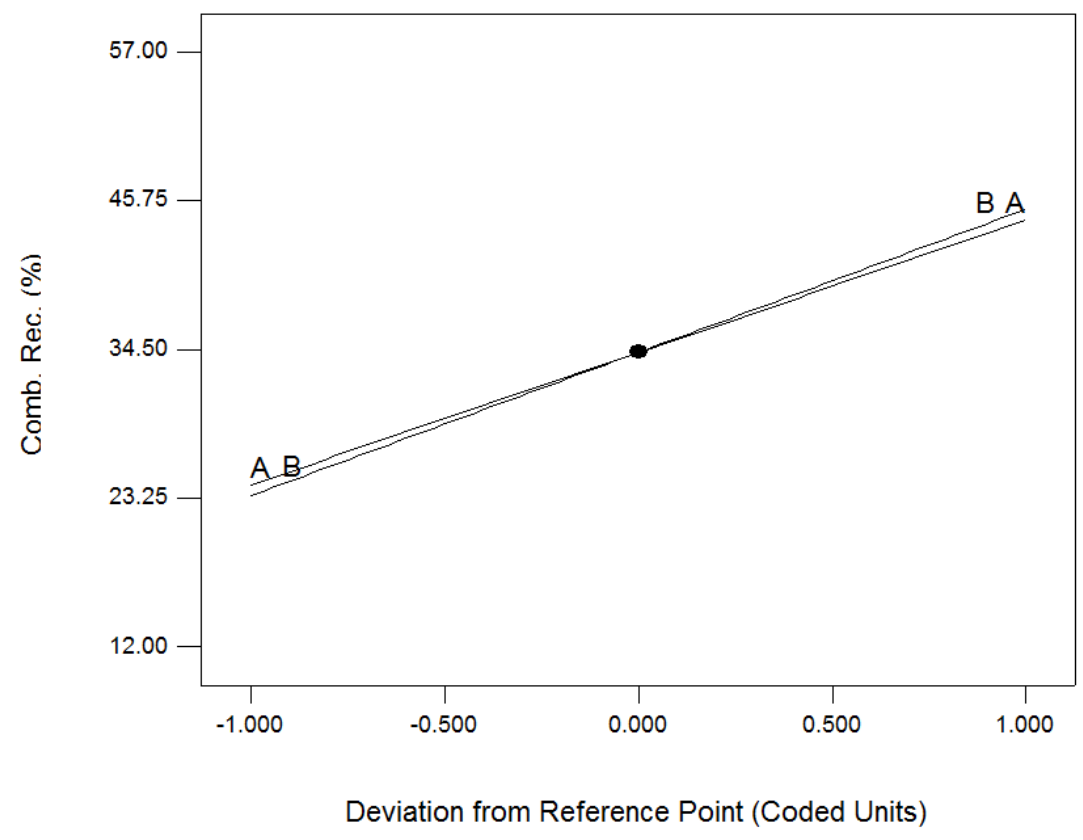

Figure 5. Main effect graphics of parameters for combustible recovery 


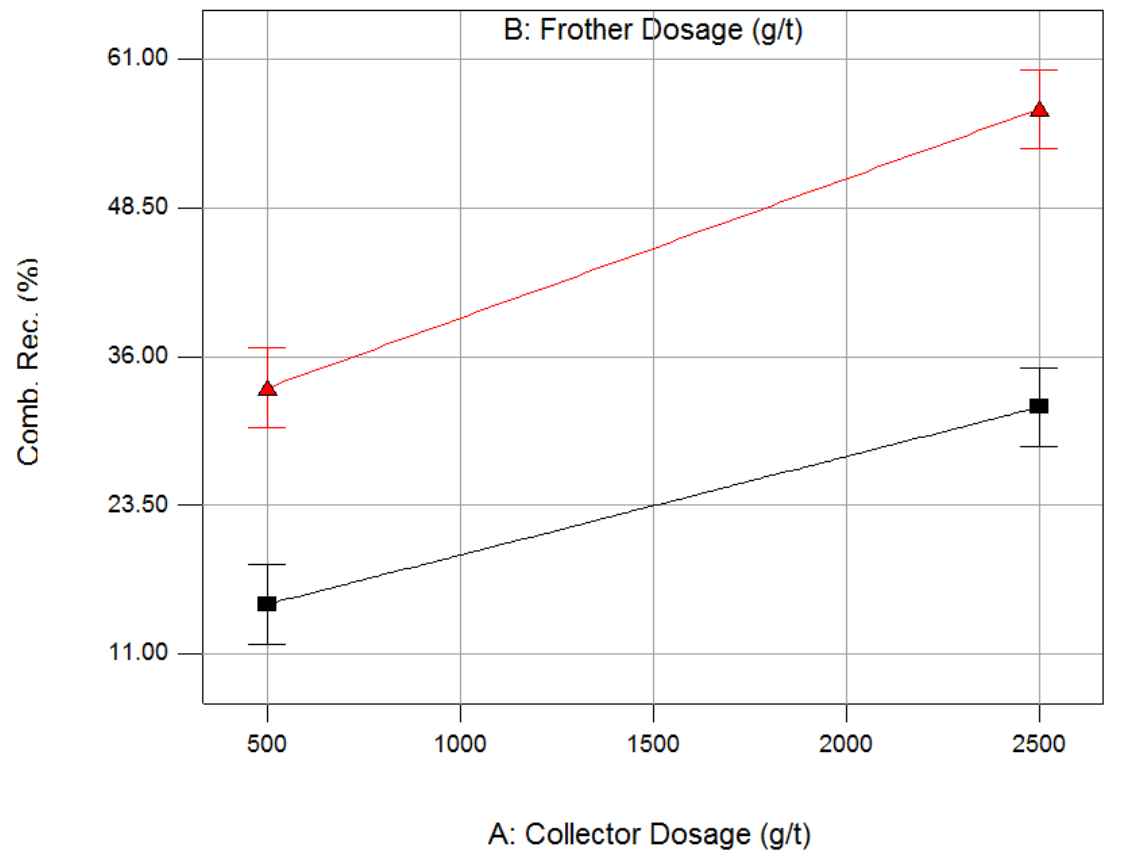

Figure 6. The interaction between collector and frother dosage for combustible recovery

\section{CONCLUSIONS}

The carbon content was increased from $9 \%$ to approximately $38 \%$ at the end of the experimental study. This result is achieved at the minimum collector dosage and middle frother dosage with approximately $23 \%$ combustible recovery. Unburned carbon content of floatation tailings obtained as $7 \%$ at these conditions does not meet the $6 \%$ unburned carbon content requirement of ASTM C618. When the collector dosage is increased to $2500 \mathrm{~g} / \mathrm{t}$, combustible recovery goes up to $50 \%$. Under these conditions, carbon content remains approximately $35 \%$, but unburned carbon content in the floatation tailing was reduced to $5.4 \%$. According to these results, the combustible matter in the floatation tailings can be reduced by using higher collector dosage in order to produce acceptable raw material for cement and concrete industry. Then, cleaning the concentrate to recycle to power plant seems to be passible. This result is in accordance with the result of another study performed on similar samples [14]. However, cleaning floatation stage can be the subject of another study.

When the results of statistical analysis are evaluated, it is clear that the mathematical model formed for combustible recovery is more powerful than the model formed for ash content. In literature, many studies performed on the coal, especially lignite with low floatability resulted in the same conclusion.

\section{REFERENCES}

[1] Koç E, Şenel MC. Dünyada ve Türkiye'de Enerji Durumu - Genel Değerlendirme. Mühendis ve Makina 2013; 639: 32-44.

[2] European Environment Agency. Projected percentage change in per capita electricity consumption from 2004 to 2030. 2009; http://www.eea.europa.eu/data-and-maps/figures/projected-percentagechange-in-per-capita-electricity-consumption-from-2004-to-2030 (Online) Accessed on: 31.07.2016. 
Öz Aksoy / Anadolu Univ. J. of Sci. and Technology - A - Appl. Sci. and Eng. 17 (3) - 2016

[3] Society for Mining, Metallurgy\&Exploration. Coal's Importance in the US and Global Energy Supply. 2012; http://www.smenet.org/about-sme/government-affairs/advocacy/technical-briefingpapers/coal-s-importance-in-the-us-and-global-energy-supp (Online) Accessed on : 31.07.2016.

[4] Kizgut S, Cuhadaroglu D, Samanli S. Stirred Grinding of Coal Bottom Ash to Be Evaluated as a Cement Additive. Energy Sources, Part A: Recovery, Utilization, and Environmental Effects 2010; 32: $1529-1539$

[5] Ozmen E. Termik santrallerden kaynaklanan küllerin yönetimi. Atık Yönetimi Sempozyumu 2011, Antalya, Turkey.

[6] Sahbaz O, Oteyaka B, Kelebek S, Ucar A, Demir U. Separation of unburned carbonaceous matter in bottom ash using Jameson cell. Separation and Purification Technology 2008; 62: 103-109.

[7] Ucar R, Koca S, Oz D, Koca H. Concentration of Unburned Carbon from Seyitomer Power Plant Bottom Ashes. 12th Balkan Mineral Processing Congress 2014, Delphi, Greece.

[8] Trifunovic PD, Marinkovic SR, Tokalic RD, Matijasevic SD. The effect of the content of unburned carbon in bottom ash on its applicability for road construction. Thermochimica Acta 2010; 498: 1-6.

[9] Kurama H, Kaya M. Usage of coal combustion bottom ash in concrete mixture. Construction and Building Materials 2007; 22: 1922-1928.

[10] Ucurum M, Toraman OY, Depci T, Yogurtcuoglu E. A study on characterization and use of flotation to separate unburned carbon in bottom ash from Cayirhan Power Plant. Energy Sources, Part A: Recovery, Utilization, and Environmental Effects 2010; 27: 562-574.

[11] Butcher K. Integrated Coal Ash Processing Plant Business Feasibility Study. Land of Sky Regional Council, North Carolina, US, 2007.

[12] Um NI, Ahn JW, Han GC, Lee SJ, Kim HS, Cho H. Flotation process in coal bottom ash and their effect on the removal of unburned carbon. Geosystem Engineering 2008; 11:4, 75-80.

[13] Yamik A, Dogruoz A. Recovery of unburned carbon by conventional flotation of bottom ashes from Tuncbilek Thermal Power Plant. The Journal of the Southern African Institute of Mining and Metallurgy 2008; 108: 171-177.

[14] Oz D, Koca S, Koca H. Recycling of Coal Combustion Wastes. Waste Management and Research 2009; 108:3, 267-273.

[15] Arenas CG, Marrero M, Leiva C, Solis-Guzman J, Arenas LF. High fire resistance in blocks containing coal combustion fly ashes and bottom ash. Waste Management 2011; 31: 1783-1789.

[16] Montgomery DC. Design and analysis of experiments. Singapore: John Wiley \&Sons; 1991.

[17] Naik P, Reddy P, Misra V. Optimization of coal flotation using statistical technique. Fuel Process 2004;85:1473-85.

[18] Naik P, Reddy PSR, Misra V. Interpretation of interaction effects and optimization of reagent dosages for fine coal flotation. Int J Miner Process 2005;75:83-90. 
Öz Aksoy / Anadolu Univ. J. of Sci. and Technology - A - Appl. Sci. and Eng. 17 (3) - 2016

[19] Azizi D, Gharabaghi M, Saeedi N, Optimization of the coal flotation procedure using the PlackettBurman design methodology and kinetic analysis. Fuel Processing Technology. 2012. 128; 111-118.

[20] Naik P, Reddy P. Effect of sodium metasilicate on natural flotability of coal. Colloid and Polymer Science. 2006. 284; 1024-1030.

[21] Oz Aksoy D, Aytar P, Toptaş Y, Çabuk A, Koca S, Koca H. Physical and physicochemical cleaning of lignite and the effect of cleaning on biodesulfurization. Fuel. 2014. 132; 158-164.

[22] Dashti A, Nasab E. Optimization of the performance of the hydrodynamic parameters on the flotation performance of coarse coal particles using design expert (DX8) software. Fuel. 2012. 107; 593600 .

[23] Xia W, Yang J, Zhu B. Flotation of oxidized coal dry-ground with collector. Powder Technology. 2012. 228; 324-326.

[24] Polat M, Polat H, Chander S. Physical and chemical interactions in coal flotation. Int J Miner Process 2003;72:199-213.

[25] Liu J, Mak T, Zhou Z, Xu Z. Fundamental study of reactive oily-bubble flotation. Miner Eng 2002;15:667-76.

[26] ASTM D3174-12 Standard Test Method for Ash in the Analysis Sample of Coal and Coke from Coal, ASTM International, West Conshohocken, PA, 2012. 